\title{
The feasibility of rejuvenating Macau's cultural tourism
}

\author{
W. I. Au \\ Urban Management Program, Technische Universität Berlin, Germany
}

\begin{abstract}
Macau, a former Portuguese colony, is a small and crowded city, located at the south-east coast of China with population of 646,800 within $30.4 \mathrm{~km}^{2}$ and has the highest population density in the world, 21,100 people per $\mathrm{km}^{2}$. In 2014 , it received over 31.5 million tourists. In theory, cultural heritage should be key drivers in the process of destination decision making due to Macau's rich history and diversity of cultures even before the success of inscription of the Historic Centre of Macau on UNESCO's World Heritage List in 2005. However, the author found out from literature that the perceived destination image inclined to be "the place to gamble", so it is not necessarily true that visitors came for cultural heritage. In fact, in addition to the image created by Macau's world renowned gaming industry, which takes up almost two-third of its industrial structure, there are more obstacles against the effort to rejuvenate Macau's cultural tourism, e.g., decision making of coach itinerary driven by commission-based business model, information filter of tour guides when introducing sites, communication ineffectiveness at tourist centres, and limitation of visiting time. Even though Macau Government Tourist Office, the destination marketing organization of Macau, has been endeavouring to diverse Macau's image as a "World Centre of Tourism and Leisure", this notion is not generally perceived by either visitors or residents and it does not seem to be changing in the near future. As a tour guide in Macau, the author is concerned with not only the trivialization of cultural heritage brought by destination image, but also the "right to the city" of residents. Therefore, the author proposes ways such as the expansion of backpacker markets, improving web markers on travelling websites, and social media, raising local awareness of cultural heritage by holding activities, etc., to rejuvenate Macau's cultural tourism.

Keywords: Macau, Macao, cultural tourism, cultural heritage, MICE.
\end{abstract}




\section{Introduction}

\subsection{Macau: the place where "East Meets West"}

In 2014, Macau received more than 31.5 million visitors in total. Out of which, the majority of them were from mainland China (67.4\%) and the others were from Hong Kong, Taiwan, Korea, Japan, etc. [1] (as shown in Table 1).

Table 1: $\quad$ Visitor arrivals in 2014 by place of residence [1].

\begin{tabular}{|l|r|r|}
\hline & \multicolumn{1}{|c|}{ Number } & Structure (\%) \\
\hline Total & $31,525,632$ & 100.0 \\
\hline Mainland China & $21,252,410$ & 67.4 \\
\hline Hong Kong & $6,426,608$ & 20.4 \\
\hline Taiwan & 953,753 & 3.0 \\
\hline Republic of Korea & 134,057 & 1.8 \\
\hline Japan & 71,818 & 1.0 \\
\hline Malaysia & 81,614 & 0.8 \\
\hline Philippines & 74,872 & 0.8 \\
\hline Indonesia & 189,189 & 0.6 \\
\hline Singapore & 59,285 & 0.6 \\
\hline Thailand & 45,049 & 0.6 \\
\hline India & 167,216 & 0.5 \\
\hline Others & 215,959 & 2.5 \\
\hline
\end{tabular}

This small but crowded city located on the south-east coast of China, has the highest population density of world [2], 21,100 capita $/ \mathrm{km}^{2}$ [3], with a population of 646,800 [4, p. 13] within $30.4 \mathrm{~km}^{2}$ [5, p. 29]. It is a place where diverse cultures exist in harmony in the form of ethnicities, architecture, languages, religions, gastronomies, etc., due to the long history as an international trading hub for imports and exports of different nations, such as Portugal (whose people first settled in Macau in 1553), and later the colonial times under Portuguese rule (1887-1999) when it was surrendered to the Portuguese by the Qing Government under the "Sino-Portuguese Treaty of Peking" signed on December 1, 1887, making Macau the one and only Portuguese colony in China.

Before signing the "Joint Declaration on the Question of Macau" by Portugal and People's Republic of China, Macau was the last European colony in Asia. On December 20, 1999, the 112 years of Portuguese colonial rule came to an end and Macau was handed over to China.

Inherited with the unique features of Eastern and Western cultures living side by side (e.g., St. Paul's College was inaugurated in 1594 as the first Western university in the Far East. St. Paul's Church was an annex of the College. Three fires happened in 1595, 1601, and 1835 respectively, at St. Paul Church. However, unlike the first two fires, after the third fire, the Church was not restored, making 
it the Ruins of St. Paul. Just next to the Ruins of St. Paul, Na Tcha Temple was inaugurated in 1888. They have been standing next to each other for over a hundred years) and sometimes as fusions of both (e.g., the Macanese Creole "Patua"), Macau poses an advantage of providing visitors experiences of immersing in contrasting yet compatible spaces where "East meets West" which coincides with the last Governor of Macau, Vasco Rocha Vieira's view of Macau:

Macao has its own identity in terms of its heritage, its way of life, and its distinctive capacity to be a meeting point and a place of tolerance. You can find oriental and western styles side by side, together with a mixture of these styles which you cannot say is west or east, simply that it is Macao [6, p. 48].

In fact, even long before the inscription of "Historic Centre of Macau" on UNESCO's World Heritage List on July 15, 2005, the trajectory of Macau's tourism development lay in cultural tourism as advised by a joint study cooperated by Pacific Asia Travel Association (PATA) and Macau Information and Tourist Centre (which later evolved into Macau Government Tourist Office, MGTO) in 1980. The findings of this study, namely "Macau: A Study of Tourism Development" was summarized by du Cros as:

- Praised the efforts at conservation of the built environment and stated that these should be copied by the private sector hoping that government would not be expected to bear the brunt of the cost of keeping Macau's heritage looking good for tourists and local people.

- To that end, the taskforce wanted to see more planning controls, incentives for private investment in heritage conservation, care with design of infrastructure and services, implement/enforce 1976 heritage decree [Decree $34 / 76 / \mathrm{M}$ ], and programs to increase local awareness of heritage values [7, p. $80]$.

\subsection{From cultural tourism to MICE tourism}

"Macao: Tourism in Transition" was another study on Macau's tourism conceived with PATA in 1994 [6]. Here, I name two of the suggestions in this study:

- Macau should make use of its advantageous geographic location to mainland China to develop into a destination of meetings, incentives, conventions and exhibitions (MICE).

- Local training and education for professions related to tourism, e.g., hotel management, airport management, tour guiding, should be institutionalized in response to tourism development.

These findings were the precursors of Macau's strategic expansion of MICE tourism from cultural tourism.

The next year, Institute for Tourism Studies (Instituto de Formação Turística; IFT) was founded while Macau International Airport was inaugurated. These two key progressions paved the path for Macau's next step of tourism development.

However, after mid-1990s, the development of Macau's tourism was challenged by several obstacles such as: 
- the 1997 Asian Financial Crisis which was prorogued in early 1996 when drastic export growth was observed;

- public security deterioration before the Handover of Macau (December 20, 1999) when triad gangs repositioned in Macau before Handover of Hong Kong (July 1, 1997) and during the late Transition Phase before Handover of Macau.

Since then, Macau's GDP was in stagnation and it was not until the year of 2000 that a positive growth of $4 \%$ finally ensued (Figure 1). This marked the turning point of Macau's economy.

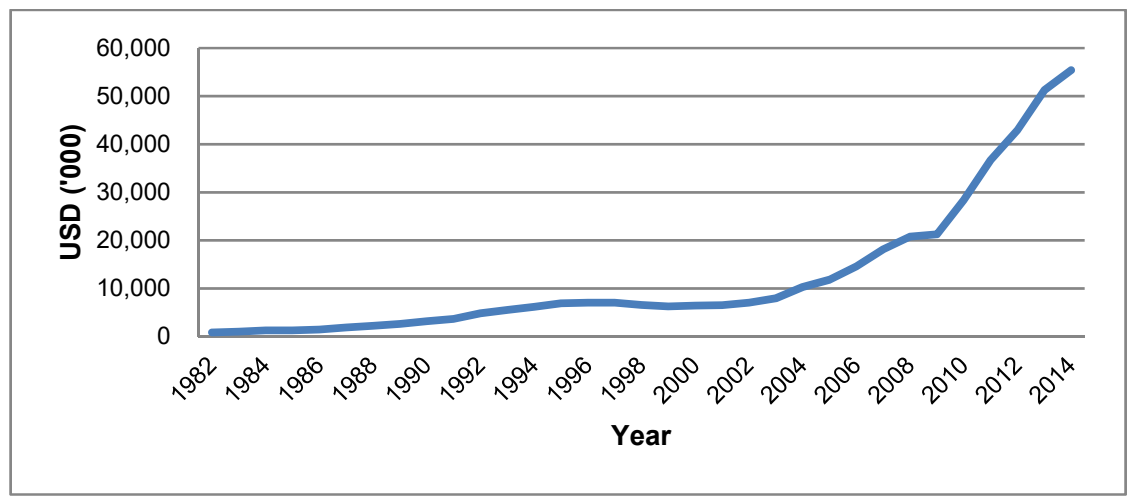

Figure 1: GDP at current (2014) prices [8, p. 36].

In the Policy Address for the fiscal year of 2001, Mr. Edmund Ho, who was in office as the Chief Executive of Macau for two terms (first term: December 20, 1999-December 20, 2004; second term: December 20, 2004-December. 20, 2009; third term: December 20, 2009-December 20, 2014, and fourth term: December 20, 2014-December 20, 2019 was assumed by Mr. Fernando Chui), hinted the strategy of Macau's tourism development in the coming years would be on the track of MICE tourism with coordination and cooperation among different institutes [9, p. 12].

With this change of direction to MICE tourism, accompanied by the effects of the disintegration of the monopoly of Macau's gaming industry in 2002 and the easing of restrictions on travelling visa application the same year in China (Figure 2), surges of tourists were observed in later years.

\section{Methodology}

This paper was intended to be a case study of tourism in the author's home city Macau. It is possible that the phenomenon described is not alike in other locations since it is not the author's purpose to contrive a generalization over cultural tourism development. 


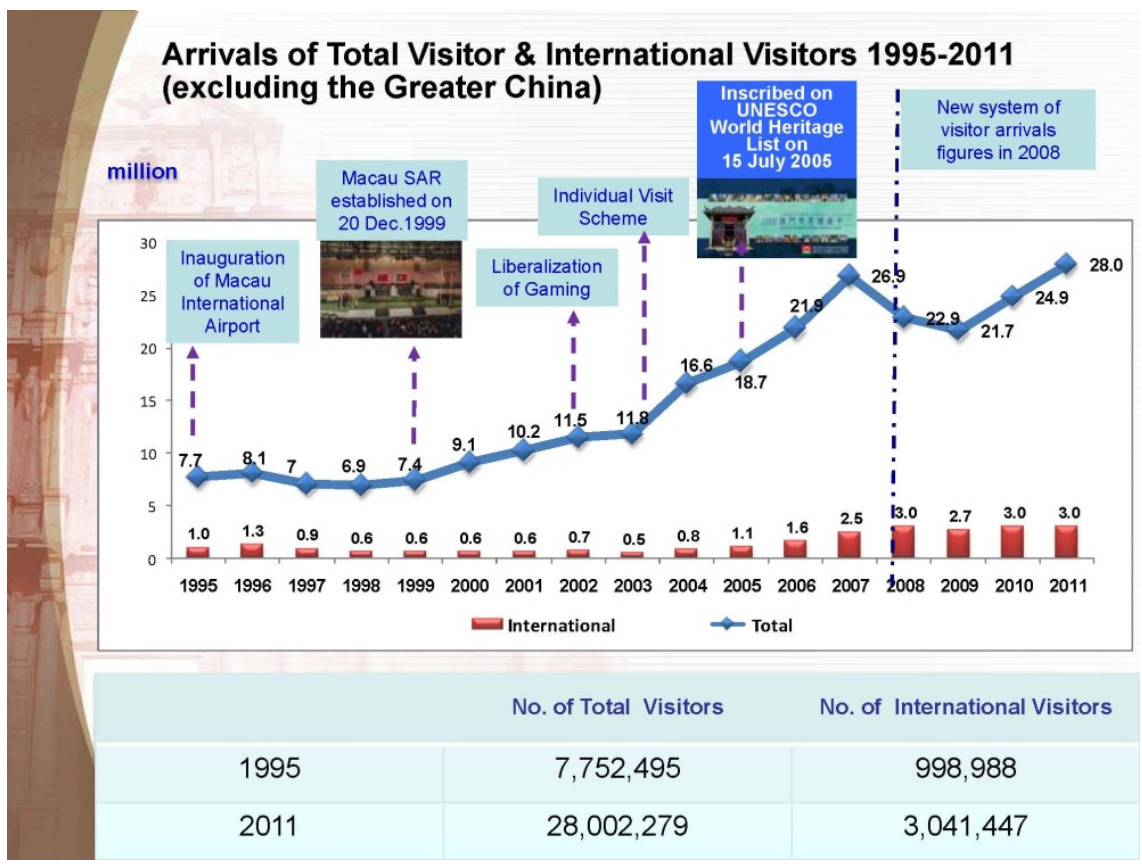

Figure 2: Arrivals of total visitors and international visitors from 1995 to 2011 $[10$, p. 8].

No survey, statistical analysis, or first-hand study was performed by the author due to the limitation of time and her geographic remoteness from the location of interest. As the means of research, the author reviewed literature, obtained information, and retrieved data from previous studies by other scholars, Macao Statistics and Census Service (DSEC), and other websites of Macau's government units.

\section{Impacts of current trajectory of tourism development}

\subsection{Destination image}

Destination marketing is significant to tourism development in any given place [11]. The image delivered by destination marketing organization (DMO) and perceived by potential tourists will affect the decision of choosing a destination but the sender's message does not necessarily coincide with recipient's perceived impression.

Despite MGTO's, Macau's DMO, efforts in diversifying Macau's image from the place to gamble to a leisure and MICE destination [12-15] accompanied by "East meets West" atmosphere, Macau remains to be seen as the former in the eyes of not only visitors, but also residents [12], [13, p. 301]. The cultural heritage, as a result, are eclipsed by the thriving gaming industry and this phenomenon does not seem to change in the near future. 


\subsection{Trivialization of cultural heritage}

This is an extension of the previous point. Macau's cultural tourism is at the stage of maturity [16]. With the prevalent image of "city of gambling" among tourists, the in-depth contents of cultural heritage, both tangible and intangible, do not stand out as a key appeal for deciding Macau as a destination $[13,17]$ which is the exact opposite expected outcome of Macau's early tourism planning. If this monotonous image persists, Macau will be reduced to a "fast food" destination. Therefore, diversification of image and tourism products [14], and rejuvenation of cultural tourism are significant to developing Macau's sustainable tourism.

\subsection{Economic impacts}

\subsubsection{Employment}

Since the majority portion of tourists' spending on traveling lies in accommodation and transportation [18, p. 130] (48.7\% of total expenditure, excluding inbound and outbound transportation fees, is attributed from shopping in the case of Macau [19, p. 40]) and the perceived destination image of Macau is inclined to be the place to gamble [12], [13, p. 301], the labour force of gaming industry and hospitality industry could be used as a crude estimation of the impact of tourism on Macau's employment pattern.

As shown in Table 2, these two industries took up altogether 100,700 out of the total labour force of 397,400 in 2014 [20]. Even without taking into account the multiplier effect of tourism on local economy, which is significant in every other places where international tourism is flourishing [21, p. 3], [22], [23, p. 1435], this amount (about a quarter) of labour forces was sufficient evidence to assert that tourism exerted a great impact on local economy.

Table 2: $\quad$ Employment in principal industries in 2014 [20].

\begin{tabular}{|l|c|c|c|}
\hline \multirow{2}{*}{ Principal industries } & \multicolumn{3}{c|}{ Employed population ('000) } \\
\cline { 2 - 4 } \multicolumn{1}{|c|}{} & 2014 & 2013 & Difference \\
\hline Gaming & 83.5 & 83.3 & 0.2 \\
\hline Construction & 52.5 & 35.3 & 17.2 \\
\hline Retail trade & 34.9 & 34.8 & 0.1 \\
\hline Restaurants and similar activities & 27.6 & 26.7 & 0.9 \\
\hline Hotels and similar activities & 27.2 & 27.6 & -0.4 \\
\hline
\end{tabular}

\subsubsection{Industrial structure}

With the employment pattern adapted to cope with tourism, the industrial structure also showed a propensity to tertiary sector, especially to "gaming and junket activities" which constituted $59.1 \%$ of the total structure in 2014 [24], making it the largest contributor of Macau's economy (Table 3). Furthermore, the gaming industry nearly doubled its structural share between 2009 and 2014 (Figures 2 and 3 ). It is thus obvious that Macau's economy is heavily dependent on tourism and gaming industry with its image as "Asia's Monte Carlo" and "Las Vegas in the East" being the distinctive driver. 
Table 3: Industrial structure of Macau (obtained from gross value-added) [24].

\begin{tabular}{|c|c|c|c|}
\hline & 2013 & 2014 & \multirow{2}{*}{$\begin{array}{l}\text { Year-on-year } \\
\text { change }(\%)\end{array}$} \\
\hline & \multicolumn{2}{|c|}{$\%$} & \\
\hline \multicolumn{4}{|l|}{ Industrial structure } \\
\hline Secondary sector & 3.7 & 5.2 & 1.5 \\
\hline Tertiary sector & 96.3 & 94.8 & -1.5 \\
\hline Gaming and junket activities & 63.9 & 59.1 & 4.9 \\
\hline Ratio of gross value added to gross output & 56.5 & 57.0 & 0.5 \\
\hline $\begin{array}{l}\text { Ratio of compensation of employees to } \\
\text { gross value added }\end{array}$ & 19.3 & 21.9 & 2.5 \\
\hline
\end{tabular}

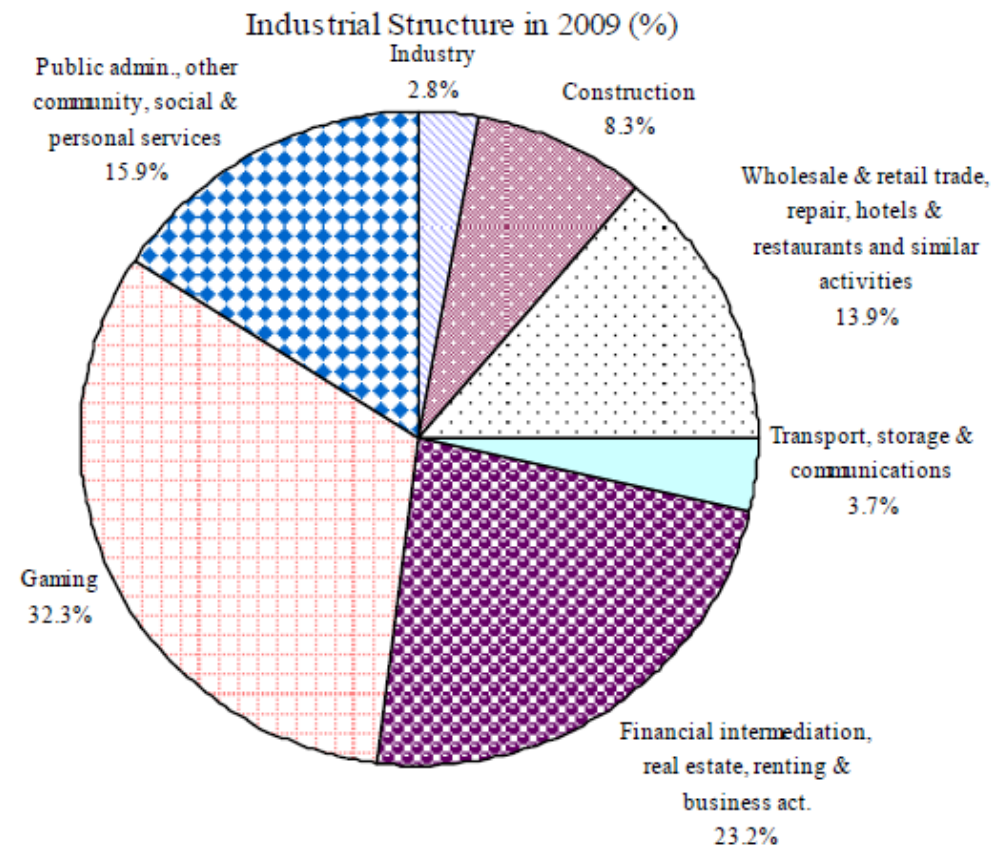

Figure 3: Industrial structure in 2009 [25].

\section{4 "Right to the City"}

Accommodating tourists makes this crowded city even more crowded. The influx of tourists also induced competition against residents in consumption of goods and services such as public transportation, facilities, public spaces, experiencing cultural heritage sites, daily necessities, etc. Residents thus tend to avoid places and spaces where people would aggregate, even sites of local importance (e.g., cultural heritage sites) are of no exception. In this sense, residents" "right to the city" [26] is diminished. If critical actions, such as forecasting tourist arrivals in long-term and short-term, are taken, both tourists and residents could enjoy the city without the latter trading off "right to the city" for economic benefits. 


\section{Structure of economic activities}

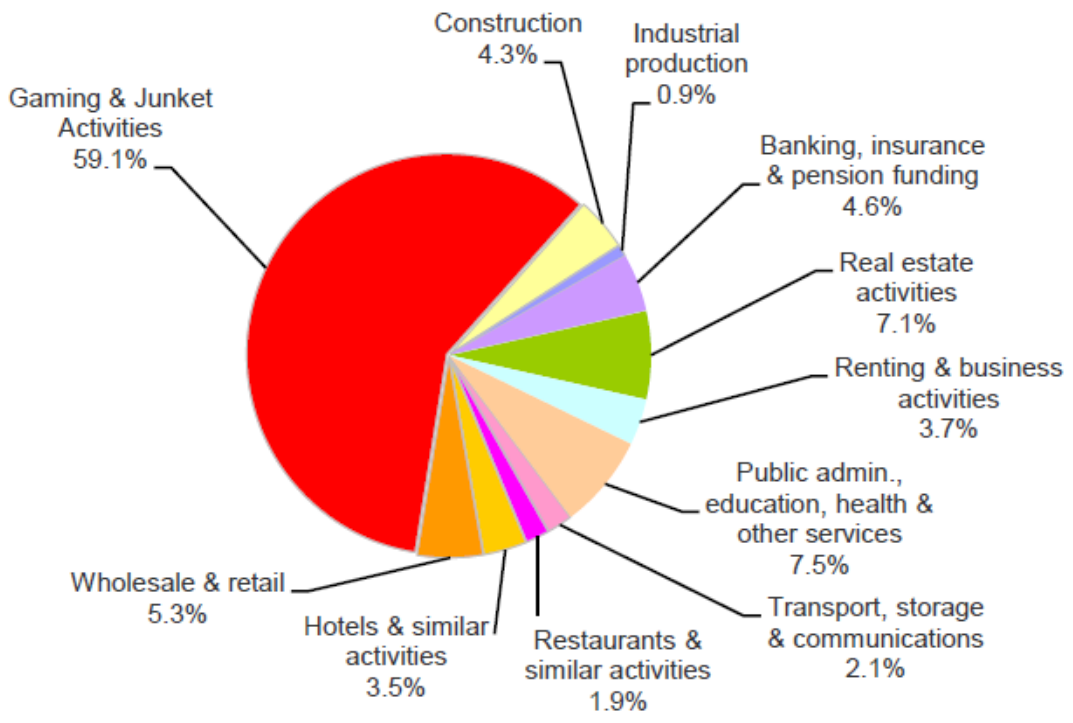

Figure 4: Industrial structure in 2014 [24].

\section{Challenges of cultural tourism}

\subsection{Gaming industry}

As mentioned above, the gaming industry is the biggest industry in Macau and its scale, in terms of industrial structure and also amount of gaming and junket activities establishments, projects an image of "the to-go place for gambling" to both visitors and prospective visitors.

Although this image is doubtlessly a persuasive appeal and a key driver in prospective visitors' decision-making process of travelling to Macau, it implies that visitors' incentives and intentions do not necessarily associate with cultural heritage in Macau. One could, therefore, deduce that while the gaming industry brings in positive economic impacts to this small city which lacks internal resources, the effect of cultural heritage to draw in visitors is dwindling.

\subsection{Itinerary decision}

Regarding itinerary decision, it could be discussed from the demand side, which refers to the visitors, and the supply side, which refers to tour operators.

On the demand side, visitors' decision on itinerary is likely to be affected by their preconception of Macau formed by its destination image, meaning that visiting gaming and junket activities establishments would be prioritized while visits to cultural heritage sites would possibly be reduced to a superficial sightseeing level. 
On the supply side, tours in Macau are offered under both commission-based model and noncommission-based model.

Tours based on the latter are sold at "real price", meaning commission is not the main source of revenue, so more cultural sites, instead of commissiongenerating places, are arranged in itineraries of these tours.

In contrast, under the commission-based model, which is prevalent in Chinese outbound tours, the market price of the tour is multiple folds lower than real monetary cost as a strategy to attract clients. It is therefore the tour guide's responsibility and liability to spur tour participants' desire of spending money at shops, e.g., restaurant, souvenir shops, in order to collect commissions to cover the costs while cultural sites are put at a lower priority in planning itineraries [27].

\subsection{Information filter}

Wong [28, p. 927] found that there was a significant difference in tour guides' interpretation of local history and information of sites when guiding tours of visitors from different countries. In her research, she concluded that:

[...] they tune their interpretation to their audiences in a significant and systematic way. [...] when dealing with a non-Chinese group, only a modest degree of encouragement by the tourists will get them to actually present Macau's colonial history, warts and all. In contrast, when guiding Chinese groups, they do not receive such encouragement [28].

It means that some historic contents of Portuguese's settlement in Macau, which constitutes and contributes to local culture and history, are blotched intentionally by tour guides in order to avoid verbal conflicts against mainland Chinese visitors because this group of visitors still see Macau's colonial past as a violation of national autonomy in Chinese history. As a result, this "information filter", as termed by Wong [28], forges a barrier to comprehensive information delivery and understanding of local cultural heritage, hampering the practice of cultural tourism.

\subsection{Communication ineffectiveness}

This was found by Wong and McKercher [29] that communication between staff at a tourist information centre and tourists was ineffective. In their study, the participants, who acted as tourists, did not always acquire clear information, e.g. general introduction and direction about cultural heritage sites from the staff. Just as "information filter", this communication ineffectiveness also hinders cultural tourism development.

\subsection{Limitation of time}

Out of the total arrivals of $31,526,000$ in 2014, more than half were same-day visitors and the average length of stay of all visitors was only one day [19]. This could be a result and a cause of not engaging in cultural tourism. The author believes that this was also one of the impacts brought by Macau's destination image. 


\section{Suggestions for rejuvenating cultural tourism}

\subsection{Tourism master plan}

PATA [14] suggested "Comprehensive Macau Tourism Master Plan" to be developed so as to reinforce Macau's position of leisure tourism destination. MGTO takes the advice and offer incentives to consultancy institutes in order to encourage submission of comprehensive short, medium and long-term master plans for Macau's tourism development. The final plan is expected to be completed in 2017 [30]. This could be an opportunity to put rejuvenation of Macau's cultural tourism on the agenda of future tourism development which, in the author's opinion, should include the activities in the subsequent points.

\subsection{Expansion of backpacker market}

Until the time of the formation of this paper, public data on Macau's backpacker tourism is not established yet. Research on backpackers in Macau, likewise, is also limited. The actual scope and impacts of backpacker tourism in Macau is therefore not known.

By analysing the contents on the Macau section of an online travelling forum, "Mofang" (The Mill), Ong and du Cros [31] found out that the choice of cultural tourism of backpackers from mainland China lay on the superficial level of sightseeing instead of in-depth level of exploration which contrasts the notion that backpackers are interested in in-depth and alternative experience of local culture [32]. Under this circumstance, it is crucial to expand the non-Chinese backpacker market together with the noncommission-based package tour market, in order to utilize them as a means of rejuvenating cultural tourism.

Experiences of planning, implementation, and research on backpacker tourism could be learnt from other countries such as Australia, where literature body of this tourism market is large while a "Backpacker Tourism Action Plan" [33] were also drawn up for a five-year (2009-2013) development. Hampton's work on cultural tourism and backpacker tourism in Indonesia, e.g., "Backpacker tourism and economic development" [34] in 1998 and "Heritage, local communities and economic development" [35] in 2005 could also provide a glimpse of the effects of backpacker tourism. However, it is important not to take these experiences out of context due to the differences in culture, history, state of development, etc.

\subsection{Placing web markers in target markets}

As mentioned in the last point, expansion of backpacker market could be a viable option to rejuvenate cultural tourism in Macau. In order to attract the targets, useful local information and markers should be placed on channels to which these targets are likely to access. In the era of information technology, it is suffice to say that the Internet is a common platform to deliver and obtain travelling information. Placing web markers on social media, travelling websites (e.g., http://www.tripadvisor.com/), backpacker websites or forums (e.g., http://www.travelindependent.info), and budget accommodation websites 
(e.g., http://www.hostelworld.com) could be a way to disseminate information and, maybe, rebrand and reshape the destination image of Macau.

Understanding the trend of targets' travelling pattern is also essential for DMO, tour operators, or other practitioners, to strategically package markers to cater prospective visitors' need of information and steer their direction of itinerary decision.

\subsection{Raising local awareness of local cultural heritage}

Raising local awareness such as encouraging locals to attend seminars, activities, programmes and producing TV shows, etc., about local cultural and history to enrich knowledge could also improve the cultural content of information delivery when encountering tourists.

In fact, ten local activities and skills, e.g., Cantonese opera, herbal tea concoction, Drunken Dragon Festival, A-Ma Faith, were recognized as local intangible cultural heritages throughout the past years [36]. To further advance the efforts in preservation, Cultural Bureau Affairs of Macau (Instituto Cultural de Macau) performed "Comprehensive Survey of Macau's Intangible Heritages" (translated by author from original text: "Levantamento Exaustivo do Património Cultural Intangível de Macau”) from October 20, 2015 to March 31, 2016 [37] to catalogue local intangible heritages as a response to the promulgation of "Cultural Heritage Protection Law" [38]. This could be seen as a good beginning of sustaining Macau's intangible heritages.

\section{Conclusions}

Even with different sources showing that the current condition in Macau is not in favour of cultural tourism, the author, as a licensed tour guide in Macau, would still answer the question "is rejuvenation of Macau's cultural tourism feasible?" with a definite "yes".

The author observed from her daily life in Macau (though not by research) that the sense of belonging and cultural pride of Macau's locals were weak, so strengthening these two attributes would be the most significant part of rejuvenating Macau's cultural tourism in the long-run. When this obstacle is overcome in the future, the possibility of local citizens' active involvement in tourism planning in aforementioned ways would become higher. At the end, it would hopefully direct Macau's tourism development trajectory on the course of sustainable cultural tourism.

Remarks: due to length limitation of this paper, in-depth explorations of other variables, activities, and planning paradigm regarding cultural tourism were not attempted. Further studies on cultural tourism would be needed.

\section{References}

[1] Macao Statistics and Census Service (DSEC), "Visitor Arrivals." Macao Statistics and Census Service (DSEC), 2015. 
[2] The World Bank, "Population density (people per sq. km of land area) | Data | Table," 2014. [Online]. Available: http://data.worldbank.org/indicator /EN.POP.DNST?order=wbapi_data_value_2014+wbapi_data_value+wbap i_data_value-last\&sort=desc. [Accessed: 21-Jan-2016].

[3] Macao Statistics and Census Service (DSEC), "Macao Statistics and Census Service (DSEC) Statistics Database," 2016. [Online]. Available: http://www.dsec.gov.mo/TimeSeriesDatabase.aspx. [Accessed: 24-Apr2016].

[4] Macao Statistics and Census Service (DSEC), "Demographic Statistics 2015." Macao Statistics and Census Service (DSEC), Mar-2016.

[5] Macao Statistics and Census Service (DSEC), "Environmental Statistics 2015." Macao Statistics and Census Service (DSEC), Apr-2016.

[6] Pacific Asia Travel Association (PATA), Macau: Tourism in Transition. Pacific Asia Travel Association, 1994.

[7] H. Du Cros, "Emerging issues for cultural tourism in Macau," J. Curr. Chin. Aff., vol. 38, no. 1, pp. 73-99, 2009.

[8] Macao Statistics and Census Service (DSEC), "Gross Domestic Product 2014.” Macao Statistics and Census Service (DSEC), 2015.

[9] Gabinete do Chefe do Executivo Região Administrativa Especial de Macau, "Policy Address for the Fiscal Year 2001 of the Government of the Macau Special Administrative Region (MSAR)." Government Information Bureau of the MSAR, 09-Nov-2000.

[10] Macau Government Tourism Office (MGTO), "Positioning and Planning of Macau as a World Centre of Tourism and Leisure," presented at the 6th UNWTO Asia / Pacific Executive Training Program on Strategic Tourism Planning, Bhutan, 2012.

[11] S. Pike and S. J. Page, "Destination Marketing Organizations and destination marketing: A narrative analysis of the literature," Tour. Manag., vol. 41, pp. 202-227, Apr. 2014.

[12] S. Choi, X. Y. Lehto, and A. M. Morrison, "Destination image representation on the web: Content analysis of Macau travel related websites," Tour. Manag., vol. 28, no. 1, pp. 118-129, Feb. 2007.

[13] W. H. Kong, H. du Cros, and C.-E. Ong, "Tourism destination image development: a lesson from Macau," Int. J. Tour. Cities, vol. 1, no. 4, pp. 299-316, Nov. 2015.

[14] Pacific Asia Travel Association (PATA), Macau Tourism Positioning: Towards a World Centre of Tourism and Leisure. Macau: Macau Government Tourist Office, 2012.

[15] Macau Government Tourism Office (MGTO), “About Macao,” 2016. [Online]. Available: http://en.macaotourism.gov.mo/plan/aboutmacao.php. [Accessed: 20-Apr-2016].

[16] Z. Meng, Y. Wei, and Y. Yu, "On Life Cycle of Cultural Heritage Engineering Tourism: A Case Study of Macau," Syst. Eng. Procedia, vol. 1, pp. 351-357, 2011. 
[17] C.-H. Huang, J.-R. Tsaur, and C.-H. Yang, "Does world heritage list really induce more tourists? Evidence from Macau," Tour. Manag., vol. 33, no. 6, pp. 1450-1457, Dec. 2012.

[18] M. Clancy, "Commodity chains, services and development: theory and preliminary evidence from the tourism industry," Rev. Int. Polit. Econ., vol. 5, no. 1, pp. 122-148, 1998.

[19] Macao Statistics and Census Service (DSEC), "Tourism Statistics 2014." Macao Statistics and Census Service (DSEC), 2015.

[20] Macao Statistics and Census Service (DSEC), "Employment Survey 2014." Macao Statistics and Census Service, Mar-2015.

[21] E. Bowitz and K. Ibenholt, "Economic impacts of cultural heritage Research and perspectives," J. Cult. Herit., vol. 10, no. 1, pp. 1-8, Jan. 2009.

[22] C. Ennew, "Understanding the economic impact of tourism," World, vol. 477, pp. 463-6, 2007.

[23] M. T. Sinclair and C. Sutcliffe, "The estimation of Keynesian income multipliers at the sub-national level," Appl. Econ., vol. 20, no. 11, pp. 14351444, Nov. 1988.

[24] Macao Statistics and Census Service (DSEC), "Macao Industrial Structure 2014." Macao Statistics and Census Service (DSEC), Jan-2016.

[25] Macao Statistics and Census Service (DSEC), "Macao Industrial Structure 2009." Macao Statistics and Census Service (DSEC), 2010.

[26] C. Schmid, "Henri Lefebvre, The Right to the City, and the New Metropolitan Mainstream," in Cities for People, Not for Profit: Critical Urban Theory and the Right to the City, Routledge, 2012.

[27] C. U. I. Wong and B. McKercher, "Day tour itineraries: Searching for the balance between commercial needs and experiential desires," Tour. Manag., vol. 33, no. 6, pp. 1360-1372, Dec. 2012.

[28] C. U. I. Wong, "The sanitization of colonial history: authenticity, heritage interpretation and the case of Macau's tour guides," J. Sustain. Tour., vol. 21, no. 6, pp. 915-931, Jul. 2013.

[29] C. U. I. Wong and B. McKercher, "Tourist information center staff as knowledge brokers," Ann. Tour. Res., vol. 38, no. 2, pp. 481-498, Apr. 2011.

[30] Macau Government Tourism Office (MGTO), "Tourism Master Plan to be completed by 2017," Apr. 2015. [Online]. Available: http://mtt.macautourism.gov.mo/201504/en/\#post-118. [Accessed: 18-Feb2016].

[31] C.-E. Ong and H. du Cros, "The Post-Mao gazes: Chinese backpackers in Macau," Ann. Tour. Res., vol. 39, no. 2, pp. 735-754, Apr. 2012.

[32] N. Ooi and J. H. Laing, "Backpacker tourism: sustainable and purposeful? Investigating the overlap between backpacker tourism and volunteer tourism motivations," J. Sustain. Tour., vol. 18, no. 2, pp. 191-206, Mar. 2010.

[33] Victorian Government, Melbourne, Victoria, "Backpacker Tourism Action Plan 2009 - 2013.pdf." Victorian Government, Melbourne, Victoria, 2009.

[34] M. P. Hampton, "Backpacker tourism and economic development.pdf," Ann. Tour. Res., vol. 25, no. 3, pp. 639-660, Jul. 1998. 
[35] M. P. Hampton, "Heritage, local communities and economic development," Ann. Tour. Res., vol. 32, no. 3, pp. 735-759, Jul. 2005.

[36] Instituto Cultural de Macau, "Breve Introdução ao Património Intangível | Levantamento Exaustivo do Património Cultural Intangível de Macau," 2016. [Online]. Available: http://www.macauheritage.net/ichsurvey/pt /?id=HeritageIntro. [Accessed: 25-Apr-2016].

[37] Instituto Cultural de Macau, "Prefácio | Levantamento Exaustivo do Património Cultural Intangível de Macau," 2016. [Online]. Available: http://www.macauheritage.net/ichsurvey/pt/. [Accessed: 25-Apr-2016].

[38] "Lei no. 11/2013- Lei de Salvaguarda do Património Cultural," Bol. of. Reg. Adm. Espec. Macau - Sér., no. 36, pp. 1859-1899, Sep. 2013. 